modation on the African model, she could increase her own tourist potential. But, alas, aid would have to come from outside even for setting up these reserves.

But unless the Bolivian revolutionises his attitude, the wildhife of the Altiplano and plains will gradually disappear, and the small animals in the remoter jungles will be the only survivors.

\title{
Vicuna Reserve in Peru
}

A RESERVE of 50,000 hectares $(123,554$ acres $)$ to protect the vicuña has been created in Peru by the Forest Service, on a high plateau (puna) 12,000 $\mathrm{ft}$. up in the mountains to the south-west of Lima. It lies between Nasca and Puquio and is called the Reserva Nacional de Pampa de Galeras. A remarkable aspect of its creation is that 8000 hectares of it were set aside for the vicuña by the indigenous community of the small village of Lucanas.

In October $1964 \mathrm{Mr}$ P. V. Pierrez, of FAO, discovered that there were some 1000 vicuña in the area, the largest known concentration anywhere in South America, which means that Peru probably has more than the combined total for Chile, Argentina and Bolivia, the other countries where they are found. The villagers were persuaded of the value to them of conserving the vicuña, with so much success that they agreed to set this land aside where there should be no inhabitants and no grazing.

With the aid of finance provided through the intervention of the Latin American Committee of the National Parks Commission of IUCN, Mr Pierrez conducted a training course for wardens, and there are now seven trained wardens with three assistants in the reserve. Management is in the hands of the Forestry Service, aided by a young biologist of the American Peace Corps, Stanley Taft.

Since Mr Pierrez first described the area in Ootober 1964, the numbers of vicuña have increased from 1000 to about 1500 , and at this rate of increase it should be possible to start cropping in two to three years, thus providing valuable fur and meat for the villagers. They will also benefit from the tourism that it is hoped to develop, for nowhere else can vicuñas be seen with certainty in such numbers. The reserve is bisected by a road, $20 \mathrm{~km}$. long, from which quite large herds can always be seen, and it is intended to build a guest house and encourage tourists.

As Mr Pierrez points out, it is not possible to persuade poor and hungry people to protect wild animals for their beauty or for science, but it can be done on economic grounds, as this success with the village of Lucanas has shown.

A resolution passed at the IUCN General Assembly congratulated the Peruvian government on the measures it has taken to conserve the vicuña and study its ecology, and urged the government to take similar measures for other important species, especially in the forests. 


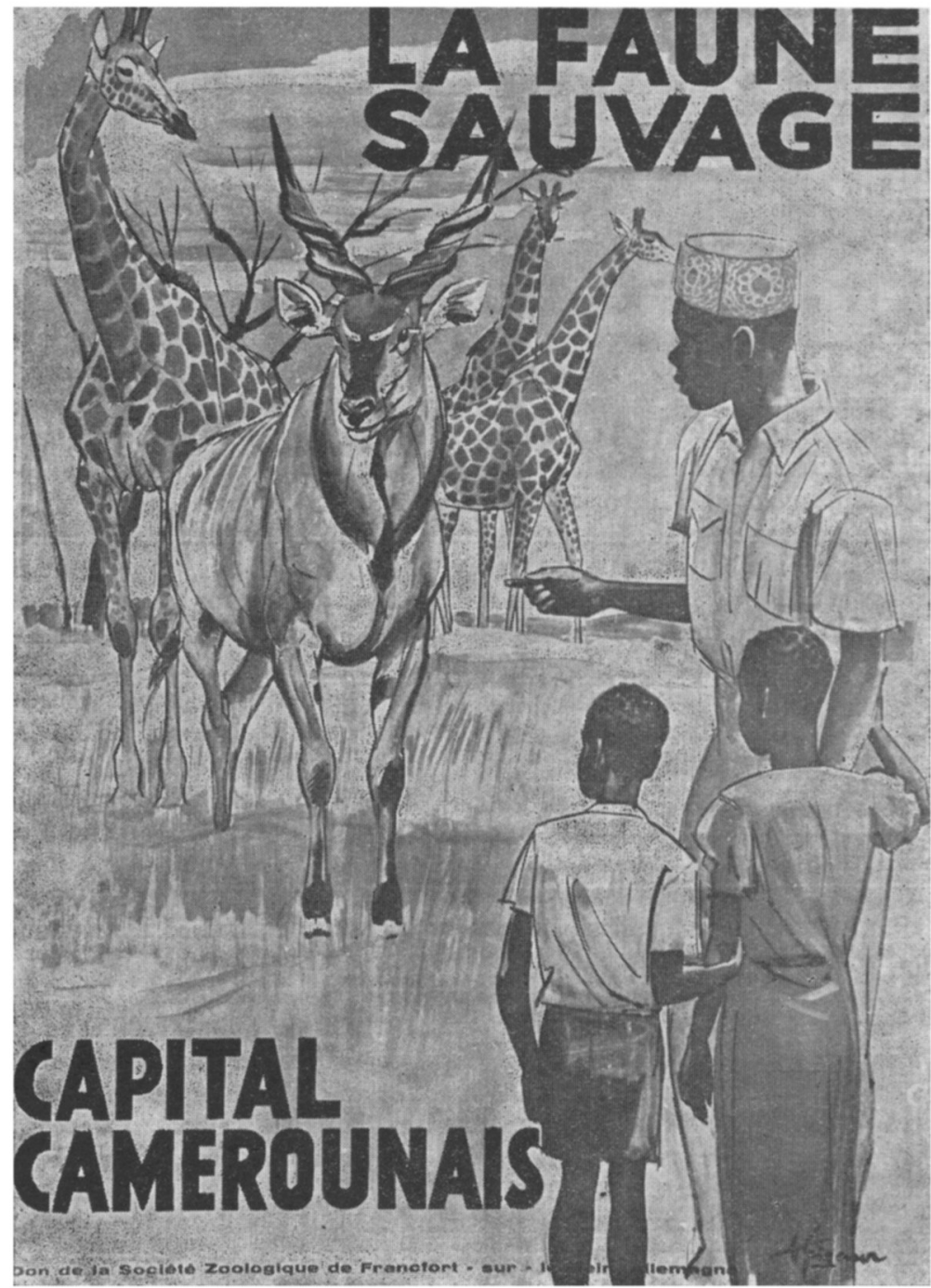

\section{CONSERYATION EDUCATION}

A Poster in colour presented to the National Parks in Cameroon by the Frankfurt Zoological Society of which Dr. Grzimek is Vice-President 